\title{
VICTORY IN HADES: THE FORGOTTEN WARS OF THE OMAN, 1957-1959 AND 1970-1976
}

S. Monick*

\section{Part 1}

It is generally conceded that the record of postWorld War II Western or pro-Western governments in countering insurgency has been marked by a long and sad succession of failures. The French endeavours to overcome insurgent forces in Indo-China and Algeria, those of the British with regard to Cyprus and Aden, the American efforts in Vietnam, the Rhodesian and Portuguese counter-offensives in the Zambezi salient, have all ended in ignominous defeat; either through military inadequacy (as in IndoChina); or, more commonly, through political pressures totally nullifying military success (as was the case in Algeria, Aden, Cyprus, the Portuguese Lusophone provinces in Africa, and Rhodesia). There is, however, one extremely significant illustration of a highly successful COIN (counter-insurgency) campaign which has received comparatively little attention; despite the fact that it has been fought in one of the most strategically crucial areas of the globe. This is the war in the Oman; or, more specifically, the series of wars which marked the years 1957-1959 and 1970-1976. The wars are unique in the annals of post-World War II military history, for reasons which will become apparent in the following article.

\section{Geo-Political Background}

The association with Hades, implicit in the title of this article, might perhaps strike the reader as somewhat perverse or fantastical; but not to those who have experienced the climatic and political environment of Oman; especially at the time of the first campaign. The geographical context in which the wars took place was the Sultanate of Oman which extends for some 500 miles along the toe Arabian Peninsula and inland into the edge of the Empty Quarter (cf. Fig i). According to a Persian proverb, in Oman the sinner has a foretaste of what awaits him in Hades. By day Oman's volcanic rock acquires the heat and airlessness of an oven, generating a nocturnal temperature of some 112 degrees Farenheit at sea level. On the northern mountains in winter the temperature drops so far below freezing point that it turns a metal water bottle into a block of ice. Beyond the valleys the wind is incessant; turbulence renders air travel a sickening experience. In the south the summer monsoon brings incessant rain from which there is no shelter in the mountains of Dhofar. Everywhere, at all seasons, wounds fester with appalling speed.

One's first impression of the Sultanate is much the same as in South Arabia (now the People's Democratic Republic of Yemen - PDRY); viz, a narrow strip cut off from the interior by barren mountains, beyond which are wide gravel plains eventually merging with the sand dunes of the Empty Quarter (cf. Fig i). It is not entirely desert, however. The shores of the Gulf of Oman (the Batina) are fringed with date palms; the great mass of the Jebel Akhdar in the north is well watered and green on the plateau (and will play a major role in the first part of this article) whilst inland are the oasis towns of Nizwa, Ibri and Firq. South-west, facing the Arabian Sea, is the province of Dhofar, which benefits from the monsoon and, like the Jebel Akhdar, is consequently green and fertile on the Jebel Qura. (Dhofar will play a leading role in Part 2 of this article.)

The country is a political anachronism, and was so to an even greater extent in the 1950's. It is an absolute monarchy in a world of 'popular' government, where political dialogue, when it exists, is traditionally violent. However, by an accident of geography the Sultanate, through its control of the Musandam Peninsula, commands the Hormuz Strait, through which passes approximately $50 \%$ of the non-Communist world's supply of crude oil. Not surprisingly, therefore, successive British governments have concluded that the protection of this Strait is vital to the British economy. 


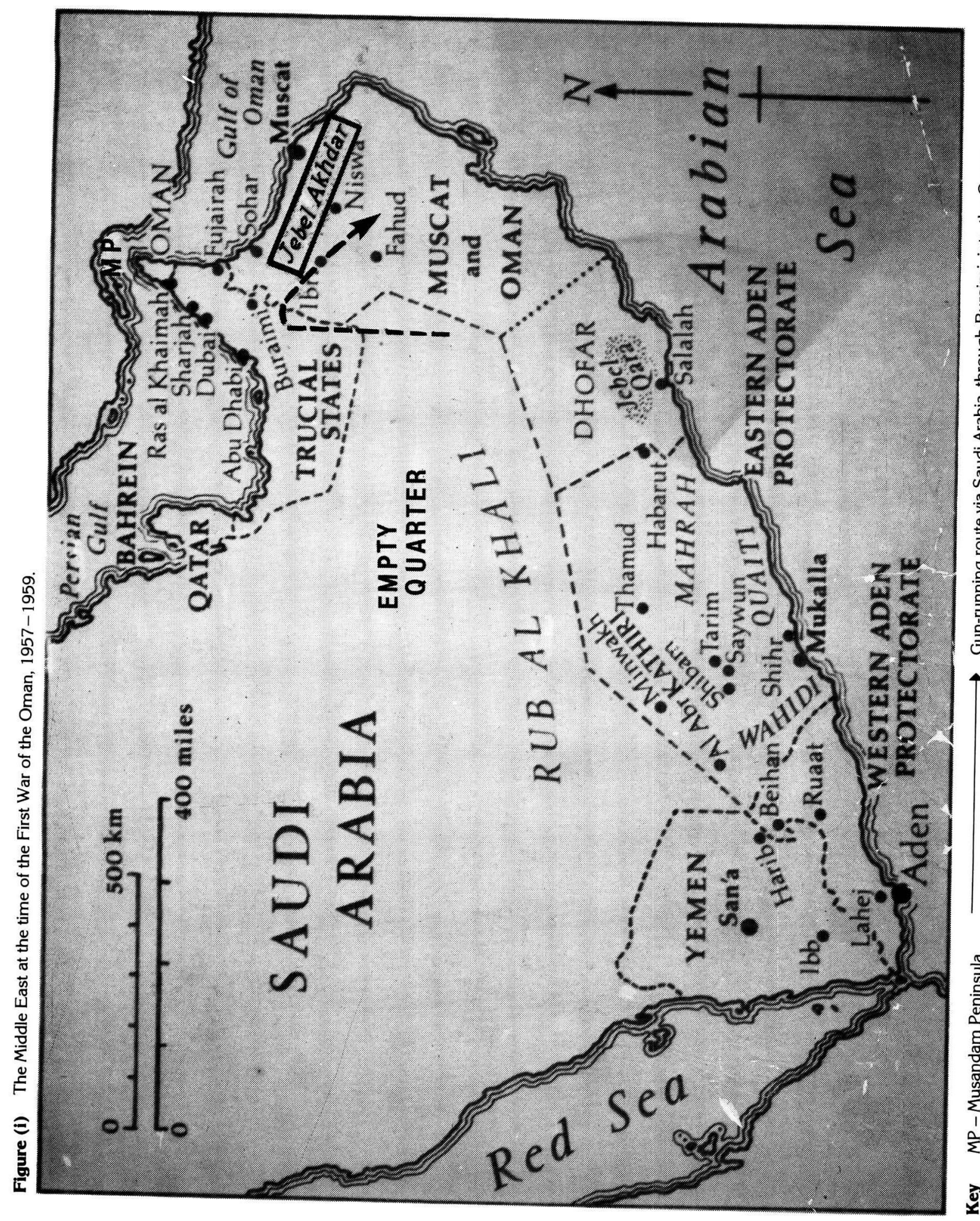

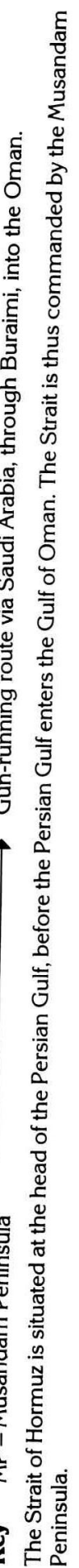

\section{Historical Background}

Oman was, until recently, the most remote and inaccessible area of the Arab world. However, it has not always been so detached from the mainstream of history. It was originally conquered by the Portuguese in 1508 , but the Omanis successfully revolted in 1650 . In the 18 th century it was a major sea power (apart from a period of Iranian ivasion during the years 1741-1743), despatching naval expeditions to western India and the East African coast to harry the Portuguese. The Sultanate's power reached its zenith in the 19th century, when its possessions included Zanzibar, Mombasa and parts of southern Persia. In the 1860's, however, Oman's Indian Ocean empire fragmented with the advent of the steamship via the Suez Canal. Mus- 
cat's commercial and maritime power thenceforth rapidly declined (Muscat is the capital and principal port). The power of the Sultan often barely extended into the interior, which was autonomous under the rule of its own imams, and he was frequently referred to as the 'Sultan of Muscat', or the 'Sultan of Muscat and Oman' Today only the name Oman is used.

From the beginning of the 19th century the sultans of Muscat and Oman had been feudatories of the British Raj. In 1798 Britain signed a treaty of protection with the Sultan, as a direct response to Napoleon's occupation of Egypt, which presented a most serious threat to Britain's sea routes to India. Thenceforward Britain exerted a substantial measure of control over Oman's affairs, although always stoutly maintaining that the Sultanate was a fully independent state. British soldiers commanded the Sultan's forces (as they do to this day); whilst British civilians undertook the (usually unrewarding) task of advising his administration. At the time of the first major war in the Oman (1957-1959) the ruler of Oman was the Sultan Said ibn Taimur, who had ruled since 1932. It would not be unfair to describe him as an arch-reactionary of great personal charm. When he had acceded to the throne the country had been desperately poor; total revenues had barely increased from the $£ 50000$ per annum of his father's time. However, in the 1950's his income began to increase slowly with British aid and payments from oil concessions; the British persuaded him (with a great degree of reluctance on the Sultan's part) to establish a development centre. The income of Oman rapidly escalated after 1968 , when oil was discovered in great quantities. However, Sultan ibn Taimur loathed development of any kind. In 1969 a distinguished British economist, John Townsend, arrived to help Sultan Said initiate 'a cautious move into the modern world'. Townsend recalls: ${ }^{1}$

'There was great poverty and disease yet nothing was done because the Sultan would not permit it. No man could leave, his village and seek work without the permission of the Sultan. No man could repair his house without the permission of the Sultan.'

In an attempt to shut out the 20th century for as long as possible, the Sultan personally issued visas to all visitors, which were severely restricted. Omani government officials and all women were only allowed to leave the country with special permission, which was rarely given. $\mathrm{He}$ forbade the inhabitants of the interior to visit coastal areas, and vice versa. The only surfaced road consisted of a few kilometres between Muscat and Matrah (Muscat's twin city). Medicines, radios, music, dancing, spectacles, trousers, cigarettes and - above all - books were all forbidden. This prohibition of books was symptomatic of the Sultan's particular dislike of education. On one occasion he told his British adviser: 'This is why you lost India, because you educated the people'. ${ }^{2}$ As a result of this policy, even in the late 1960's there were only three small primary schools. Hence, Omanis who wished to study became political exiles; some, predictably, did so in the Soviet union and other Eastern bloc states, others elsewhere in the Middle East. Medical services suffered from the same total lack of development as education. By the late 1960's, in a population of approximately 750000 (estimates vary between a million and half a million; no census has ever been taken), there was one hospital (belonging to an American Protestant Mission) to deal with a people ridden with endemic diseases such as malaria, leprosy, tubercolosis and trachoma and an infant mortality rate among the highest in the world.

Such an ultra-reactionary approach was, inevitably, accompanied by rule of the most despotic character. In 1958 Sultan Said retired to live premanently at his palace at Salalah, the capital of Dhofar province in the far southern corner of his Sultanate on the borders of South Yemen. Thence he ruled by radio-telephone, never leaving his palace. He instilled such a fear within his Omani subjects that very few dared to defy him or undertake any initiatives whatsoever in order to improve their situation. The minor punishments for infringing the Sultan's prohibitions included flogging and imprisonment. Perhaps the most serious - and dreaded - collective punishment, in a society in which water was - and is the crucial source of life (because of its scarcity), was the cementing over of a community's wells. As an official British press briefing stated, Said was 'a Medieval and somewhat despotic ruler'.

However, it is important to reiterate the point made above; viz. that the Sultan's power over the entire country was distinctly vague. The tribes of the interior had been in the habit, for many years, of playing off their religious leader, the Imam of Oman, against the Sultan, and, as a result, there had been numerous wars between the two. The Treaty of Sib (1920) had endeavoured to place relations between the Sultan and Imam in somewhat better order. The British acted as 'honest broker'. It was eventually agreed that the Imam 
would acknowledge the Sultan's paramountcy in exchange for the Sultan agreeing to substantial autonomy for the Omani tribes. The agreement functioned well until 1954; principally on account of the personalities of the Sultan and Imam. In that year, however, the old Imam died and his elected successor, Ghalib bin Ali, was quite different in character. He was weak, irresolute and strongly influenced by his brother, Talib bin Ali, who was both able and ambitious, and also by one Sheikh Suleiman bin Himyar, paramount Sheikh of the Beni Riyam tribe. This tribe had long been opposed to the Abu Saidi (the Sultan's tribe) and Sheikh Suleiman had been an unwilling guest of the Sultan in Muscat. He and Talib made a formidable combination, manipulating the irresolute Imam. This was the state of affairs which formed the source of the insurrection against the Sultan's rule which erupted in 1957.

\section{Subversion via Saudi Arabia}

King Abdul Aziz ibn Saud of Saudi Arabia (who reigned between 1953 and 1964) had at his disposal vast sums of money from oil revenues. From 1952 onwards no effort was spared to bribe the Omanis from their allegiance and to supply them with weapons and ammunition with which to assert their independence from Sultan Said ibn Taimur. The Sultan lacked both the money with which to counter-bribe, and the soldiers with which to establish his authority in Oman. The Saudis' objective was to extend their frontiers wherever oil might be found. The Imam's objective was to establish a religious republic independent of the Sultan within Oman. If to achieve this it would be necessary to cede certain territories to the Saudis, it was a price that was acceptable. Soon there was a virtual state of war between the Sultan and the Imam.

\section{Preliminary Skirmishes}

The first skirmish to erupt in the Oman, in 1952, was, essentially, a manifestation not of internal conflict between the central authority and separatist political-religious factions but, rather, aggrandisement on the part of an external power (i.e. Saudi Arabia). The issue centred upon a group of villages known as Buraimi Oasis, which was situated where the boundaries between Saudi Arabia, Muscat and Oman, and the Sheikhdom of Abu Dhabi meet. The Sultan of Oman and the Sheikh of Abu Dhabi both laid claims to parts of Buraimi, the major portion (consisting of six villages) being allocated to Abu
Dhabi. The Sultan of Oman controlled the other three. These claims were disputed on historical grounds by the Saudis, who claimed Buraimi in entirety. Matters were further complicated due to the fact that Buraimi lay at the very base of the Oman Peninsula at the edge of the sand desert. It was a natural concentration point for caravan tracks and was thus the gateway to Oman proper. There was also ample water for both men and animals. Inevitably, therefore, Buraimi became an important market; and, with equal inevitability, in view of the convergance of caravan routes, consequent access to Oman, and trading facilities, Buraimi bacame an important channel for the passage of arms and ammunition with which the Saudis were hoping to win friends and influence people in the Sultanate of Oman. The dispute between Saudi Arabia on the one hand, and on the other the British Government acting on behalf of Sheikh Shakbut of Abu Dhabi and the Sultanate of Oman, dragged on in a desultory fashion for some years; principally because neither side could provide a conclusive case. Then, in 1952, the Saudis suddenly lost patience, borrowed a quantity of trucks from the Arab-American Oil Company (ARAMCO) and occupied Buraimi. The infuriated Sultan mustered some 12000 tribesmen with a view to expelling them, but he was disuaded from doing so at the last moment by the British. The Sultan's advance guard was half-way to Buraimi when the British Consul-General (Mr Leslie Chauncy) arrived from Muscat (after a celebrated dash up the Batina coast by Land Rover) and managed to prevent an armed clash between the rival forces. The British wished to avoid a clash of interests with the United States, who were supporting the Saudis. Accordingly, the British persuaded the Sultan to submit the case to international arbitration. As a result, the forces of Saudi Arabia and those supporting the Sultan (in the form of the Trucial Oman Levies) maintained an uneasy occupation of the Buraimi Oasis for the ensuing three years; until, in 1955, the Saudis were expelled after a surprise attack by the Trucial Oman Levies (who were subsequently redessignated the Trucial Oman Scouts - TOS - in 1956, and will feature at later points in this article).

It will have become apparent from the foregoing narrative that intervention in Oman's internal affairs by external powers (in the case of Buraimi, by Saudi Arabia) was compounded by the collusion of oil companies (specifically, ARAMCO), who saw in the Sultan's profound antagonism to 20th century style economic development a se- 
rious barrier to their obtaining extensive concessions. The question of oil concessions underlay the next clash of interests which erupted; but, on this particular occasion, directly involving separatist pressure groups, in the form of dissident religious factions (the Imam) and tribal separatism (the Beni Riyam tribe), both compounded by an external power (Saudi Arabia).

A British subsidiary of the Iraq Petroleum Company wished to drill for oil at Fahud in Oman. The Sultan claimed the right under the Treaty of Sib (cf. above) to negotiate the terms of the concession. The Imam, encouraged by the Saudis, asserted otherwise. In 1955 the Sultan decided to settle the matter by a show of force, and the Imam and his followers accepted the Sultan's authority without any further fighting. The Sultan left his palace at Salalah, 1000 miles to the south, accompanied by a miscellaneous assortment of slaves and Baluchi soldiers (cf. below), in addition to James Morris of the London Times. By the time this cavalcade had arrived at Fahud, all opposition had been bloodlessly overcome. The Sultan received the submission of his subjects (the Imam had, in the intervening period, retired to his village) and paid a visit to Buraimi for a short period with his neighbour, Sheikh Shakhbut of Abu Dhabi. The Sultan concluded his business with a brief but triumphal tour of his dominions. Sheikh Suleiman bin Himyar made an unwilling submission and became, yet again, a prisoner of his master in Muscat. There followed, for two uneasy years, a kind of peace in the Oman.

\section{The Sultan's Forces: The Role of Mercenaries}

The force with which the Sultan had successfully demonstrated his power was but an apology for an army. At Beit al Falaj ('the house of the water channel') was based the Muscat Regiment, approximately 250 strong and employed principally on guard duties in the camp and in Muscat itself. Beit al Falaj also served as the Headquarters of the Sultan's Armed Forces (SAF) and an artillery troop consisting of two 5,5 inch and two $75 \mathrm{~mm}$ guns; the latter being of the pack variety. At Nizwa, the chief town of Oman, was stationed the Muscat and Oman Field Force, also approximately 250 strong and with the mobility which a mixed selection of battered trucks and Land Rovers could provide. This force was financed by the oil companies in return for the (somewhat uncertain) protection that it provided for its employees. To the south of Dhofar, at Salalah, was the 'Dhofar Force', 200 strong and controlled directly by the Sultan. It was commanded by Maj St John Armitage, formerly of the Arab Legion, and was independent of the Muscat and Oman Field Force.

In addition, one had the Trucial Oman Scouts, who had made their presence so felt at Buraimi in 1955 (cf. above). The TOS had been founded in 1951 by Maj Hankin-Turvin, formerly of the Arab Legion. The force was originally intended to be the private army, so to speak, of the British political service in the Persian Gulf, employed in escort duties. However, its brief also included protection of oil exploration teams, with the subsidiary task of suppressing tribal raids and maintaining some degree of law and order among the factious tribes. However, its fundamental objective was the safeguarding of British interests along the Trucial Coast (and, therefore, within the Trucial States, which were powerfully dependent upon Britain through Treaty obligations of 1835,1853 and 1892). For precisely this reason, Oman was included in its sphere of responsibility or interest, as this territory was strategically vital to Britain (and, indeed, to the Western world generally, for reasons which have been cited above). Furthermore, the ranks of the TOS consisted mainly of Arab tribesmen from both the Trucial States (principally Abu Dhabi) and that part of Oman contiguous with the Trucial States. Nevertheless, the TOS did not form part of the SAF; although, as will be discussed below, it played a major role in the COIN operations in the Oman. In 1971 the TOS was re-designated the Union Defence Force, upon its being placed under the control of the newly constituted United Arab Emirates (a Federation of the former Trucial States instituted in 1971).

The TOS corresponded far more closely to a British force than did the SAF, in three major respects. First, it was funded and organized by the British Government, with the consent and cooperation of the rulers of the Trucial States (which comprised Abu Dhabi, Dubai, Sharjah, Ajman, Umm al Qaiwain, Ras al Qaiwain, al Khaimah and Fujairah). Second, it had extremely close relationships with these Trucial States through treaty obligations (cf. above); to such a degree, indeed, that Britain claimed protectorate rights over the territories. Thirdly, there was a strong leavening of British officers within the TOS who remained members of the formal British military establishment (i.e. they were seconded from regular British Army units, to which they eventually returned). In addition to these seconded 
officers on temporary loan to the TOS there were also, of course, a large number of British contract officers. Nevertheless, the contrast is most marked in this respect, in the 1950's, with the $\mathrm{SAF}$; in which the officers were entirely on contract service until the secondment of Col Smiley as Chief of Staff to the SAF (cf. below), together with his Brigade Major, Maj John Goddard, RE, in 1958. The TOS could not properly be described as a British unit as it did not form an integral part of the British Defence Force (as did the Sudan Defence Force, King's African Rifles or Royal West African Frontier Force, for example). The reason for this resided in the fact that the Trucial States were never formal dependencies of the British Crown (in the same manner as Kenya, Nigeria, Sudan, Malta, Northern Rhodesia, etc.) despite the powerful treaty relationships between the two.

The overall commander of the very mixed collection of soldiers that comprised the SAF was Col Pat Waterfield, formerly of the Royal Artillery, who had arrived from India in 1954 to command the Muscat Regiment. The remaining British officers, approximately a dozen in number, were employed on a contract basis by the Sultan. There were some colourful characters included in this group. Especially prominent was Maj Jasper Coates, who had formerly been the senior RAF officer in the Gulf. (He had in fact held the rank of Group Captain, so his appointment in the Sultan's forces involved a reduction in rank of two steps). There was a leavening of ex-Indian Army officers, which is hardly surprising in view of the long Indian influence in the Arabian Gulf; the first Commanding Officer of the Muscat Regiment, for example, was Capt Leslie Hirst of the 10th Gurkha Rifles, who went to Oman from Burma in 1941. Another officer who came from India was Maj Richard Anderson, who had served with the Green Howards and Rajputana Rifles. The longest serving officer was Brig Colin Maxwell, who had served in the Royal Scots Fusiliers and $\mathrm{Pa}$ lestine Police before joining the SAF. All the British officers under contract with the Sultan (i.e. his entire officer corps) had previous military service, many as regular officers with the Army or RAF; whilst a few had served in the Colonial Police.

In modern parlance they would be described as mercanaries, a word that has, in the previous two decades, acquired perjorative implications. However, the well known military historian, Maj Gen James Lunt, has an interesting comment on this mercenary contingent in the SAF which places the issue of mercenaries in a somewhat different context of thought ${ }^{3}$ :

$\therefore$... there have always been mercenaries and there always will be. A mercenary can be defined as a soldier hired into foreign service - and from the beginning of recorded history men have offered their swords for hire without, until recently, attracting criticism. Byron, who fought for Greek independence, and Charles Gordon, who fought for the Emperor of China and the Khedive of Egypt, were regarded not as bloodthirsty thugs but instead as national heroes. The Swiss Guard of the Kings of France and the Irish Catholics who served under the Bourbons and Habsburgs were mercenaries; and so, for that matter, are the Gurkhas.

Inevitably, in the declining years of a great empire, there will be men who are attracted by conditions of service such as those offered by the Sultan of Muscat. The climate and living conditions were harsh, but the pay was better than in the British Army. There was an absence of the bureaucratic and pettifogging regulations of a more conventional military career. The individual officer possessed much more responsibility than in Britain or BAOR - (British Army of the Rhine) - Leave was more generous .... 'Embryonic Lawrences' was how one young British officer sarcastically described some of the contract officers he met in Muscat, and perhaps some of them may have given that impression. But they were none the worse for that, and they did at least stay long enough for their soldiers to know and understand them. It is hard to see how the Sultan's Forces could have got underway without them.'

It should be borne in mind that this employment of senior British officers in what might be termed a mercenary capacity was an important aspect of the Sultan's political strategy. As he informed Col David Smiley:

'You must know that all revolutions in the Arab world are led by colonels. That is why I employ you. I am having no Arab colonels in my army.'4

Thus, the Sultan was determined that none of his Arab subjects were to attain commissioned rank in his army; with the consequent danger of establishing a power base for insurrection. 
The same principle underlay the extensive employment of Baluchis in the ranks of the SAF. Indeed, the ratio of Baluchis to Arabs was approximately three to one; the recruitment of indigenous Arabs being mainly among the coastal tribes. (The indigenous inhabitants of the interior were largely ignored with regard to potential recruits; possibly because of the powerful separatist and factious elements traditionally characterizing them.) The Baluchis' homeland was Baluchistan, which spans both Pakistan and Iran. The territory is harsh and infertile; there is insufficient cultivable land in Baluchistan to maintain a large population, with the result that its inhabitants have for centuries provided the main mercenary contingent in the Gulf. The channel through which they were recruited was Gwador, an enclave of the Sultanate on the opposite coast of the Gulf, in Pakistan. (Gwador was ceded to Pakistan in 1958.) Although Arabic was, obviously, the lingua franca of the SAF, among themselves the Baluchis spoke either their own patois or Urdu. (It is curious that there is no reference to Baluchi officers serving with the SAF. Documentation concerning the Omani campaigns is scarce, but neither Col Smiley's paper, nor the relevant chapters in Maj Gen Lunt's work, Imperial Sunset: Frontier Soldiering in the 20th century - cf. bibliography - which provide the principal source documentation for this article - make any reference to them.)

It should, perhaps, be emphasized that contract service with the Sultan on the part of British exservice personnel or, indeed, with any indigenous military force in the Middle East, was very far indeed from being a sinecure. The tragic fate of Maj Pat Gray in 1966 (cf. below) was anticipated in 1953 when a mutiny broke out at Buraimi among the troops garrisoning it. (These comprised a company of discharged Arab soldiers recruited in Aden, and of very poor military worth). In the course of the mutiny their Commanding Officer, Maj Otto Thwaites (formerly of the 9th Lancers) was killed (together with an RAF Medical Officer on loan to the unit and a Jordanian RSM). Early in 1958, Captain Peter Chambers (formerly of the Royal Hampshire Regiment and SAS), who had only recently joined the TOS, was killed when leading a counter-attack after an ambush near Izki, at the foot of the Jebel Akhndar. Moreover, in July 1958, when mining incidents were particularly extensive (cf. below), virtually every officer of the Northern Frontier Regiment was blown up, some more than once (although casualties were not normally serious).

\section{7: The Insurrection Erupts in Earnest}

It was in June 1957 that the long smouldering discontent in the Oman erupted with overwhelming power. There had, in actual fact, been tentative moves towards an uprising in March 1957, when Sheikh Ibrahim bin Issa al Harthi arrived in the Sharquiya accompanied by approximately 70 hard core followers, with a view to initiating a revolt against the Sultan. In April and May, accordingly, the Oman Regiment (on 1 March 1957 the Muscat and Oman Field Force had been thus re-designated, without any marked effect upon its efficiency) received a series of orders and counter-orders to oppose Ibrahim bin Issa's men, but finally returned to Firq utterly frustrated, as they had been forbidden to take any action against Ibrahim bin Issa's followers because the Sultanate authorities were negotiating with him at the same time. Finally Ibrahim was summoned to Muscat to see the Sultan. For reasons yet to be explained he chose to go without guarantee of safe conduct; and was duly detailed in Muscat by the Sultan. The reasons for Ibrahim's action can only be guessed; but it was probable that he was waiting for Talib (returning from exile in Cairo) to land on the Batina coast on a certain day, which was to be the signal for him to strike. In the event Talib's boat broke down and he had to return to Damman for repairs. Possibly Ibrahim thought that the plans had miscarried and so had quickly moved to vindicate himself with the Sultan. A few days later, however, Talib sailed again and this time successfully landed on the Batina coast with between 60 and 80 hard core followers. On 14 June 1957 Talib's forces joined with those of Ghalib's in their home village of Balat Sait and raised the standard of revolt there.

On 7 July 1958 the Oman Regiment moved from Firq towards Hamra, where they hoped to intercept Talib's forces, and arrived on the next day. On the night of 12/13 July an event occurred which decisively altered the balance of the opposing forces. Suleiman bin Himyar broke his parole in Muscat and made his way to join forces with the other two rebels. He ordered the Beni Riyam tribe to rally to his aid and, together with the Beni Hinna, these two tribes virtually controlled the Jebel Akhdar. In addition, they controlled the area around the base of the jebel, with only the area (doubtfully) controlled by the Abryeen tribe around Hamra within the province of the Sultan's authority. This placed the Oman Regiment in an extremely difficult position, and so the decision was taken to withdraw. The re- 
sults of this decision are concisely stated by Col Smiley :

\begin{abstract}
'The less said about the operation the better, but the result was a disaster. The Sultan's forces were sniped at and ambushed all the way back to Nizwa, casualties were sustained, vehicles blew up on mines, men began to desert, some fed into the desert where they died, and one company was taken prisoner. The remnants barely halted at their base at Firq but, abandoning quantities of arms and equipment, continued to retreat to Fahud, many miles to the south, where they arrived on 17th July.'
\end{abstract}

Within ten days, therefore, the rebel forces appeared to have totally seized control of the interior of Oman.

Even more damaging to the Sultan's forces, however, was their loss of the important town of Nizwa, where the Imam's white standard replaned the Sultan's red one. The massarcre of the Oman Regiment, therefore, and its consequences, represented a total disaster. Col Waterfield was on leave and it fell to Maj Pat Gray as the senior officer present in Muscat (and, incidentally, a South African who had been a regular officer in the South African Army, and who was murdered by his own troops in 1966 whilst in command of the Hadhrami Bedouin Legion in the Eastern Aden Protectorates of the South Arabian Federation), to report the sorry story to the Sultan. Sultan Said replied, with characteristic fatalism: 'It is not your fault. It is no my fault. It is nobody's fault. It was just unforeseen.' Whilst this comment is a commendable manifestation of self-control, it did not offer any constructive mehod of overcoming a highly critical situation. He had neither the finances nor the officers to establish the type of army he needed to re-establish his authority in Oman. It was, moreover, as clear to him as to his advisers that, unless he did recapture Nizwa, Muscat itself must ultimately fall.

The Imam Ghalib, Talib and Suleiman bin Himyar ('The Terrible Trio', as they were termed by the Gulf Times) were, predictably, lavishly supplied with arms by the Saudis. In addition, the insurgents enjoyed an additional powerful weapon in the form of propaganda support from Radio Cairo. In 1957 Nasser's power as leader of the 'struggle' against 'anti-colonial, imperialist' forces in the Gulf was at its zenith; his 'Voice of the Arabs' from Cairo exercising a profound in- fluence on sophisticated and unsophisticated Arab listeners alike. Britain was, of course, the principal target of this vituperative propaganda; but, closely associated with her, were the feudal Sheikhs and Sultans sneeringly referred to, inevitably, as 'the British lackeys'. ${ }^{6}$

The headquarters of the insurgents was the Jebel Akhdar. This has been referred to above, in the section dealing with the geographical context of Oman. It is appropriate at this point, however, to discuss this vital geographical feature in greater detail. The Jebel Akhdar ('Green Mountain') is an elevated fertile plateau twenty miles by 10 in area, on average 6500 feet above sea level, locked behind sheer cliffs of rock and shale ascending to 10000 feet above a sweltering plain. On the plateau Talib had assembled an offensive guerrilla force of 500 armed men, supported by 180 marksmen. There were only twelve known easily defended approaches to the plateau. A small picket placed astride any of these tracks could delay a greatly superior force for a considerable time; nor was it an easy task to outflank these pickets. The enemy were provided with ample stocks of modern weapons, including .5 in Browning machine guns and quantities of mines with which, during the course of raids on the surrounding plain, they blew up 150 vehicles (including 18 British Ferret Scout cars) between March and November 1958. Although short of food and suffering from bombing attacks by the Sultan's air force, they remained a formidable enemy, apparently able to resist indefinitely. Indeed, the strength of the insurgents' base was testified to by no less a personage than the (then) Foreign Secretary, Mr Selwyn Lloyd, on 23 July 1957 in the House of Commons, when he was categorical that there was 'no question ... of large scale operations by British troops on the ground': He went on to state that in view of the high temperatures in Oman at that time of year, it would be an example of military futulity to seek to employ ground forces in the desert areas. Equally, however, the policy of control of factious tribesmen through the medium of air control, so faithfully adhered to since the 1920's ${ }^{7}$, was proved totally bankrupt within the Omani context. Cavernous retreats, in which the tribesmen could conceal themselves during bombing attacks, proved to be a marked feature of the Jebel Akhdar.

\section{Britain Intervenes}

The British Government could not afford to ignore the situation in Oman, for three central 
reasons. First, one had the crucial strategic position of the Sultanate (cf. above, with regard to Oman's geo-politicacl context). Second, the Sultan had granted important concessions for oil exploration to the Iraq Petroleum Company, in which Britain had a major share. Third, the Sultan was allied to Britain by treaty (although treaty obligations have proved the least binding of factors determining British policy in the post-World War II period). Accordingly, a British military force was hastily assembled with the object of recapturing Nizwa and restoring the Sultan's authority in Oman. The force, commanded by Brig J.A.R. Robertson, comprised a rifle company of The Cameronians (Scottish Rifles) (together with a skeleton battalion headquarters of that regiment and the medium machine-gun and mortar platoons), and one Troop of the 15/19 King's Hussars. Within Oman it was assisted by the battered remnants of the Oman Regiment, the recently formed Northern Frontier Regiment, and two Squadrons of the TOS. This last, known as 'Carter Force', after its new commander, had been moved to Ibri, 80 miles south of Buraimi, shortly after the destruction of the majority of the Sultan's forces (cf. above). Ibri, on the border between Abu Dhabi and Oman, was strategically important in so far as it covered the most probable of the routes by which Saudi mines and other weapons were being smuggled to the Imam and his supporters at Nizwa.

As soon as Robertson had concentrated his force and the RAF Venom aircraft from Bahrain and Sharjah had played their part in 'softening' the enemy, the advance on Nizwa began. The principal danger accrued from anti-tank mines, which had been liberally scattered along the few tracks, and searching for them inevitably imposed delay. However, the Imam displayed little resistance, and Nizwa was recaptured without loss. At Nizwa Robertson's force was joined by a column hastily scraped together from the Sultan's army and designated 'Haughcol', after its commander, Maj Haugh, who was one of the survivors of the disasters which had befallen the Oman Regiment. This column had driven from Muscat across difficult terrain and not without resistance; it was intended to garrison Nizwa after the town's recapture.

However, although the Sultan's flag flew once again at Nizwa, the source of the insurrection remained secure behind the ramparts of the Jebel Akhdar. Brig Robertson, who had served his military apprenticeship leading Gurkhas up barren slopes on the North-West frontier of India, assessed the possibilities of storming the heights of the 'Green Mountain' and destroying the Sultan's enemies; and concluded that it was simply not practicable. He lacked the troops (in both quantitative and qualitative terms; the qualitative aspect arising from the fact that the troops had no training in the extremely demanding standards of mountain warfare), artillery support, and also the logistic support that would enable the soldiers to climb to almost 7000 feet up almost sheer cliffs and still be fit to fight after they had attained the heights. In such a temperature (cf. above), dehydration leading to heatstroke is a continual risk, and Brig Robertson could see no method by which adequate quantities of drinking water could be supplied to his assault troops. Thankfully handing over to 'Haughcol', the British contingent departed. (This is the official interpretation. Others have argued that the British evacuation was motivated purely by political considerations; this school of thought has argued that the British Government was anxious to withdraw all Britisn troops before the Omani question was debated in the United Nations, since certain Arab states had moved to place it on the agenda). Before the British had completed their evacuation, they destroyed the villages of Tanuf and Kamah, Suleiman's large fort in Birket-alMauz having been thoroughly bombarded by the Royal Air Force. By September 1957 all British troops had been withdrawn with the exception of a Troop of Ferret Scout cars of the 15/19 Hussars, later relieved by the 13/18 Hussars. The two Squadrons of the Trucial Oman Scouts were moved to Aziba, the oil company camp near Muscat, whence tank landing craft transported them back to Sharjah, the main RAF staging post in the Persian Gulf. The Oman Regiment was disbanded.

\section{Assault upon the Green Mountain}

\section{Britain intervenes in earnest:}

Suleiman bin Himyar (the self-styled 'Lord of the Green Mountain'), together with his two confederates, had to be destroyed in their mountain fastness if the Sultan's authority in Oman was ever to be secured. Unless this were effected, then no degree of success in the surrounding country would remove the dangers of insurgency. However, this objective remained impossible of execution with the military resources at the disposal of the Sultan. The magnitude of the task may be gauged by the fact that the Jebel Akhdar had last been conquered by the 
Persians during the 18th century, in the course of their invasion of the country (cf. above, with regard to the historical background of Oman), reputedly with the loss of the 9000 of the 10000 soldiers with which they had assaulted the 'Green Mountain'.

The scale of the operation demanded active British military intervention of far greater dimensions than hitherto. Accordingly, a mission was despatched from London in January 1958, headed by Mr Julian Amery, the (then) Under-Secretary at the Colonial Office. After intensive negotiations the British agreed to assist in the training, expansion, and equipping of the Sultan's forces. This initiated, in effect, the process whereby British regular officers were ultimately seconded to the Sultan's army. The quid pro pro was that the Sultan agreed to a plan of civil development which was to be overseen by Col Boustead, who had until recently been Resident Adviser in the Eastern Aden Protectorates. The Sultan agreed to this proposal, despite the opposition of some of his advisers. He also had to accept a new commander of his army, since the British Government was, understandably, determined to have its own representative overseeing the projected expansion, in which large sums of British money were involved. The War Office nominated Col David Smiley of the 'Blues' (Royal Horse Guards), who was at that time Military Attache in Stockholm. Smiley and Amery had served together with SOE (Special Operations Executive) in Albania in 1944 and were old friends. Amery warned Smiley of the peculiar problems which would attend the latter's task when he stated: 'We give the Sultan help; we sometimes give him advice; but we do not give him orders.' Smiley's proposed appointment created an awkward situation with regard to Waterfield who, to reiterate, had previously served for some years as commander of the SAF and who had the Sultan's confidence. The problem was resolved by a traditionally British compromise. Waterfield became the Sultan's Military Secretary and Defence Minister, leaving Smiley in command of the troops. (Waterfield, like the Sultan's Foreign Secretary, Neil Innes, remained a very important component of the Omani governmental machine. Both men knew how to deal with their secretive and justifiably suspicious master and both to some extent shared his view that it was necessary to 'hasten slowly' in a land as intrinsically backward as Oman.)

It is apparent from Smiley's account of his service in $\mathrm{Oman}^{8}$ that he found conditions far from agreeable when he first arrived at Beit al Falaj in April 1958. There was no air conditioning (the temperature in Smiley's bedroom was 112 degrees Farenheit and rising), sanitation was primitive and there was no running water. Nor could it have been easy for him to adjust to the type of army that he had been sent to command. It was still smarting from defeat (despite the re-occupation of Nizwa) and, as a result, lacking in spirit. Moreover, the initial problem concerning the position of Waterfield was symptomatic of the entire question of relations between seconded British officers and the contract officers whose allegiance was entirely to the Sultan. Until Smiley's arrival, accompanied by his Brigade Major, Maj John Goddard of the Royal Engineers, there had been no regular officers serving with the SAF. Thus, the new arrivals were, predictably, regarded with some suspicion by the more established - and longer suffering - officer element within the SAF.

Smiley arrived in Oman in April 1958, in his new role as chief of Staff of the SAF, and spent the first months after his arrival touring his new command. It is appropriate at this point to reiterate the forces placed at Smiley's disposal, incorporating the re-organization which had occurred in the SAF since the destruction of the Oman Regiment:

(1) Force HQ (HQ SAF) was at Beit al Falaj. This is approximately five miles from Muscat and situated at a strategic point where all the 'roads' (although one hesitates to term them thus; 'routes' or 'tracks' would perhaps be a better designation at this point of Oman's history) from the interior to Muscat pass. An airstrip for light aircraft adjoined the camp and, when Smiley arrived, contained two single-engined Pioneer aircraft employed for communication flights and casualty evacuation, flown by RAF pilots.

(2) The Muscat Regiment of some 250 men. This was, to reiterate, based at Beit al Falaj and was completely non-operational, as they were all used for guard duties in Muscat. It also employed a company at Izki, but this was shortly incorporated into the Northern Frontier Regiment as the company was administered from Nizwa and was, in effect, the remnants of the disbanded Oman Regiment.

(3) The Northern Frontier Regiment (NFR) of approximately 450 men and based at Nizwa, with a company at Kamah.

(4) The Artillery Troop, based at Kamah, from where two 5,5 in guns could shell the main 
rebel villages of Habib, Saiq, and Sharaijah on the top of the Jebel. The troops also manned two $75 \mathrm{~mm}$ gun howitzers.

(5) The Depot. This was situated at Ghobra, approximately 15 miles from Muscat, and consisted of one British officer with a staff of 25 , and 60 (later 120) recruits.

(6) Attached British troops stationed in the Oman, under the command of Smiley. These comprised:- one Troop of 13/18 Hussars at Nizwa, later increased to two Troops; one officer and eight NCO's of the Royal Marines attached as instructors to the NFR; and various small detachments such as Royal Corps of Signals operators at Beit al Falaj and Nizwa, RAF ground crews for the Pioneer aircraft, etc. These British troops, prior to the arrival of reinforcements of contingents from the Life Guards (cf. 8 below) and Special Air Service Regiment, amounted to less than 50.

(7) Two Squadrons of the TOS, one stationed at Ibri and the other at Izki.

(8) A full squadron of the Life Guards, reinforcing the two Squadrons of the TOS. The Life Guards Squadron replaced the two Troops of the Regiment which it was originally intended should relieve the 13/18 Hussars. Between 16 August and 28 September 1958 ' $D$ ' Squadron, the Life Guards, under the command of Maj Kenneth Diaire, arrived in Oman.

The sum total of these forces amounted to less than 1000 troops. This number dramatically contrasts with the ludicrous estimate propagated by Radio Cairo; to the effect that Smiley had 120000 troops under his command. The problem facing this force was how it could blockade the Jebel Akhdar, and simultaneously prevent the roads around its base from being sealed ('roads' being a euphemistic term for cart tracks), re-organize and retrain the force already committed to active operations; and, finally, to assault or capture the Jebel and drive out the rebel leaders and their hard core followers.

\section{The problem of gun-running:}

The problem of mines, as intimated above, was a particularly pressing problem. As increasing numbers reached the Imam and his two colleagues, travel in the interior of Oman bacame correspondingly dangerous. This mining seriously interfered with oil exploration. The seriousness of the problem may be gauged by the fact that, between January 1958 and January
1959, of a grand total of 73 casualties, approximately 50 resulted from mine incidents. Late in June 1958 the rebels succeeded in running a lorryload of reinforcements and weapons from Shariah, through the customs post at Aswad, down the Batina coast, through three posts of Government tribal guards, past Awabi, and down the Wadi Beni Kharus to a point where they unloaded the supplies and burnt the lorry. It is an incredible fact that this old ex-British lorry carried four Browning .5 in anti-aircraft guns; nine heavy mortars; 13 Bren guns and their ammunition; three wireless sets; and no less than 40 men. By chance Smiley was only one day behind this lorry on his tour and attempted to follow it up the Wadi Kharus. However, the rebels had wisely laid mines in the Wadi and a Land Rover behind Smiley blew up, badly wounding the Arab soldiers and his escort. In actual fact, the gun-running incident in June 1958 led to the first of the measures which stifled this aid to the rebels. Smiley placed a platoon of the Muscat Regiment in Awabi. One week later a section of the same unit was placed in the customs post at Aswad, in the extreme north of the Batina coast, with orders to search every lorry entering from the Trucial States. Early in October 1958 a company of the NFR occupied Tanuf. This cut the last supply line through which camels and donkeys were able to convey supplies to the rebels, and from that time hence they had to rely upon man-carried supplies. The occupation of Tanuf, it later transpired, was a serious blow to Talib, whos HQ was in a cave not far from there. A number of attacks were made upon the SAF's positions in Tanuf, which were not only regularly mortared, but also attacked in strength. These attacks were driven off with losses to the enemy.

\section{Reconnaissance patrols:}

The second major task confronting smiley was to send reconnaissance patrols up the tracks leading to the Jebel Akhdar in order to pinpoint the enemy pickets, improving the very inadequate maps, and thus to help in deciding at what point to frontally assault the Jebel. In the second week of November 1958 a small patrol of the Muscat Regiment, led by Maj Tony Hart, a contract officer, found a way to the top of the Green Mountain which was unguarded. This was the very first time that a member of the Sultan's forces had reached the summit and, as far as is known, the enemy had been completely unaware of the patrol. The Track in question was on the north side of the Jebel and was approached from the 
Awabi base up a track leading from a village called Hijir (cf. Fig ii). Though steep, it could be traversed by donkeys, despite the fact that one section of it was a straight climb up over 80 steps cut out of the mountains by the Persians.
Improvement in morale; the tide begins to turn in the Sultan's favour:

The ascent of the Jebel Akhdar by maj Hart's patrol, combined with the occupation of Tanuf

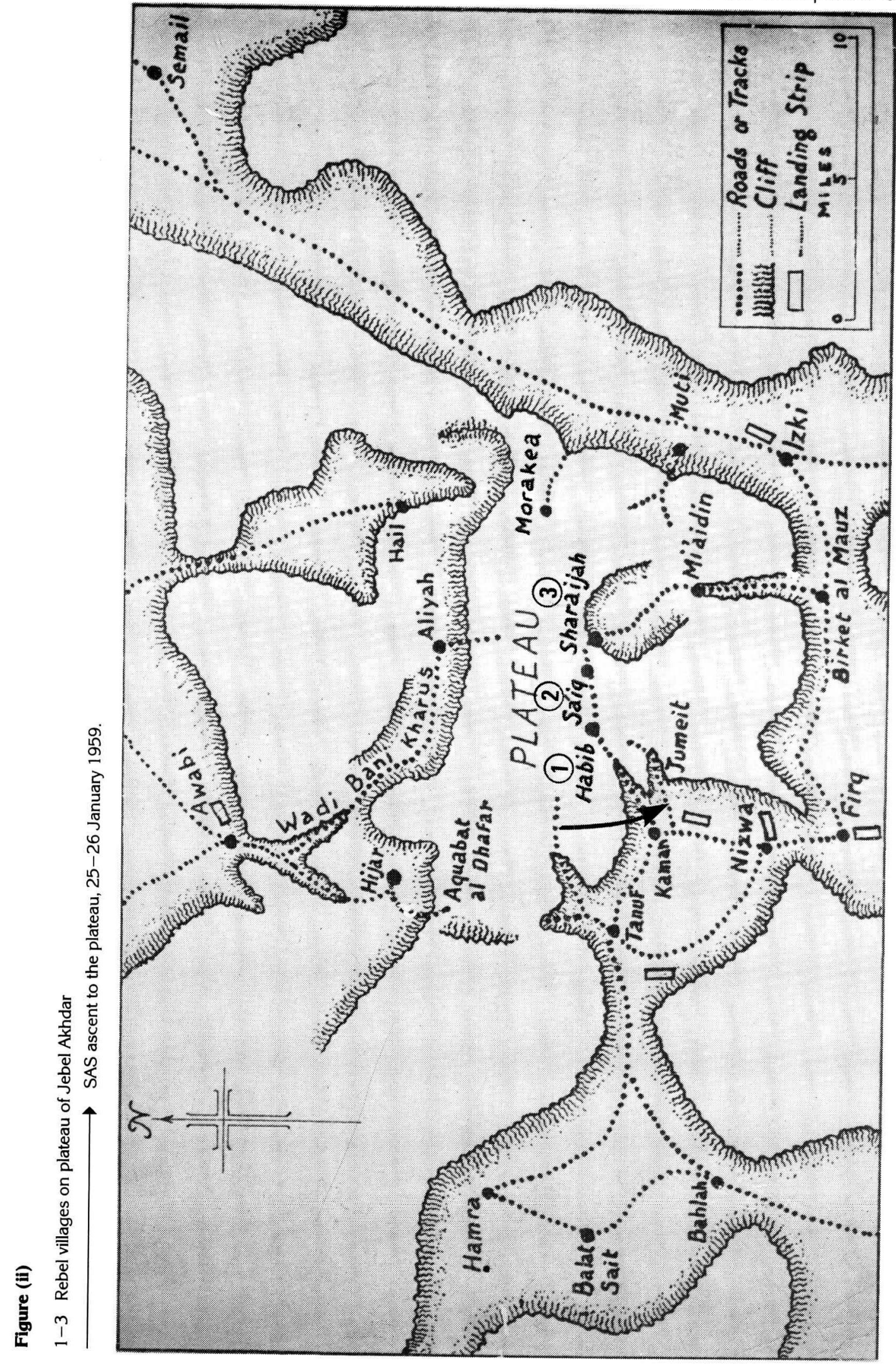


and the gradual influence of the Royal Marines training mission helped considerably in implementing the third of Col Smiley's objectives; viz. to instil a more aggressive spirit into the Sultan's forces by a series of actions in which they would gain experience and, by successful actions, improve their morale. An important stage in this process was the occupation, by the TOS, of the village of Yanqul, through which it was suspected that arms were still reaching the Jebel; whilst the NFR increased its aggressive patrols. The effect to the increasingly aggressive approach which began to characterize the Sultan's forces - manifested in both the assertive patrols and curtailment of the gun-running activities, led to the rebels initiating overtures for peace. Consequently, a short armistice ensued in which the rebels ceased their shelling and patrolling. As it became apparent that the terms that the rebels were demanding were quite unacceptable to the Sultan, the armistice came to an end and both sides restarted hostilities. It was thought at the time that the rebels were feeling hard pressed whilst the blockade of the Jebel Akhadar was beginning to yield its effects; subsequent captured documents confirmed this impression.

\section{The SAS intervenes:}

Smiley's efforts up to November 1958 had localized, so to speak, the infection. Whilst the situation in Oman had been stabilized and gun-running activities drastically curtailed, the source of the infection remained; the rebel presence in their base on the 'Green Mountain'. At the end of October 1958 it was decided not to proceed with certain earlier plans for an attack on the Jebel, and it appeared, therefore, that the stalemate would continue. One plan that could not be aborted was the arrival of 200 Somali donkeys which were required to carry supplies during the assault on the Jebel. These pathetically little animals were desperately small compared with the Omani Jebel donkey and had not even been trained to take a saddle upon their backs. Smiley's forces had neither the men nor the time to train them, and they could carry approximately only $50 \mathrm{lbs}$, compared with the jebel donkeys (capable of carrying $120 \mathrm{lbs}$ ). Moreover, they were hopelessly weak to deal with the task, despite assurances of their prowess in Somaliland. They became, ultimately, an embarrassment to the Sultan's forces and, although used in the final operations, were more of a hindrance than a help.

The only method of resolving the stalemate ap- peared to be more active intervention by British troops. However, as intimated above, within the context of the exigencies of mountain warfare, this intervention had to be effected by units of a highly specialized nature. Smiley felt that a normal infantry battalion would not possess the standards required for assault upon the Jebel without a great deal of additional training. It bears reiteration at this point that the only known routes up the Jebel were a number of donkey tracks. Any other method of ascent was considered to the quite impossible. Hence, Smiley's opinion that only elitist units in which Commando tactics and mountain warfare featured to a very great extent could be of real assistance. In conversations with Christopher Soames, the (then) Secretary of State for War, in June 1958, Smiley had broached the question for more extensive and direct British intervention. He had requested a brigade of British troops to be despatched to Oman in order to assault the Jebel and finally resolve the problem. Political considerations profoundly, and predictably, inhibited the scale of British intervention and it became apparent that two battalions were the utmost that Smiley could expect. He asked if one of these battalions could either be a Royal Marine Commando, a Parachute Battalion, or a Special Air Service (SAS) Regiment. No British troops could, however, hope to operate until the cold weather commenced in Septembers. In June/July, day shade temperatures reached to points in excess of 110 degrees Farenheit and, on one day at Nizwa, it reached to above 125 degrees. (Of the approximately 50 British personnel attached to Smiley's forces, two died of heat exhaustion and 45 were flown out for hospital treatment suffering from the same complaint. Climatic conditions not only restricted the time in which British troops could arrive, but also the actual duration of their presence. Medical authorities estimated that two months were the maximum period for British troops to serve in Oman without being relieved.

In the last week of October Lt Col Tony DeaneDrummond, then commanding 22 SAS Regiment in Malaya, visited Oman, with the obect of ascertaining as to whether operations in the Jebel were a suitable task for SAS troops. The answer was decidedly in the affirmative, and DeaneDrummond enthusiastically recommended to his superiors - political and military - the employment of one of his Squadrone returning from Malaya to operate in the assault upon the Jebel. Accordingly, in the final week of November 1958 , 'D' Squadron 22 SAS Regiment arrived in Malaya under the command of Maj John Watts. The 
Squadron was organized into four troops, or patrols, of 16 men each, and its overall number was less than 80. (The SAS is organized in the basis unit of a Troop. Each Troop forms part of a larger unit known as a Squadron, of which 22 SAS - the British regular unit - has four. Each Squadron thus consists of four troops in addition to the Squadron commander (a Major), a second-incommand, a Sergeant Major, quartermaster and clerks - a total of 72 men and six officers.) However, this was more than compensated for by the lavish scale of their fire power which, in addition to their FN rifles (then a recent innovation, it should be remembered, and not available to the Sultan's forces in large numbers), included Browning machine guns and Energa grenades. A base camp was erected at Beit al Falaj, but Maj Watts rapidly organized his troops to carry out a number of patrols and acclimatize the men to the type of terrain in which they would have to operate. They had, to reiterate, arrived directly from the jungles of Malaya, and a drastic change of tactics was, therefore, required for the assault upon the steep, rocky Jebel.

It was decided to split the SAS troops. Accordingly, half were despatched to Tanuf where they carried out a number of offensive patrols in the area of Tanuf and Kamah slabs; these were huge rock formations several thousand feet high where Talib was known to have his $\mathrm{HQ}$. During one of these patrols the SAS had a skirmish with the rebels in which they certainly killed one, but they themselves had one of their bes NCO's ( $\mathrm{Cpl}$ D. Swindells, MM); shot through the heart as he showed himself on the skyline. This incident led to a new-found respect on the part of the SAS contingent for the enemy, whose markmanship they had previously tended to under-estimate.

The other two Troops were sent to Awabi and thence up the Jebel by the route discovered by Maj Hart (cf. above, under reconnaissance patrols), who accompanied the SAS, together with some of his men from the Muscat Regiment (On all the SAS patrols, men from the SAF were attached, to the mutual benefit of both.) These two Troops were led by Capt Roderic (Rory) Walker. They were guided by an extremely nervous Sheikh. At the top, near the twin peak called 'Sabrina' (named after a well known female TV personality of the 1950's), the Sheikh fell upon his knees and thanked Allah for deliverance. In the same area Walker led an exploratory raid against Sabrina on the night of 27 December. The two Troops were detected just before they reached the top. One Troop was climbing a rope up a fault in the cliff when the guerrillas above called out, 'Come on Johnny', and opened fire. Walker hauled himself further up the rope and lobbed a grenade over the top; one guerrilla was killed instantly and his comrades scattered. This enabled Walker to scale the top of the plateau, his men following; in the darkness they killed another eight of the enemy.

On the south side of the mountain, a small patrol had discovered a cave utilized by the guerrillas to guard the main approach to the Jebel Akhdar. It was also a principal store for weapons and ammunition. Two nights later two SAS Troops moved in on it. One of these, under the command of Capt (later Maj) Peter de la Cour de la Billière, made a ten hour march through enemy territory in order to approach the cave from an unexpected direction. It then crept up to a point 200 yards from the cave mouth, sited a 3,5 in rocket-launcher, and waited. The only point from which the SAS party could open fire was below the cave, which meant that the rocket crew had to kneel in order to use the weapon. The same firing point was in a natural amphitheatre whos upper slopes were honeycombed by many small caves sheltering enemy snipers. At dawn, as the first of the guerrillas sleepily emerged, the attacking party poured a hail of missiles and machine-gun fire into the main cave. Describing this action subsequently, Deane-Drummond ${ }^{9}$ wrote:

'Even such withering fire did not cause the rebels to panic or surrender. They quickly dropped into fire positions and returned the best they could. Reloading and firing the 3,3 in from the standing position became interesting.

What made it particlarly interesting ('infuriating' would perhaps be a more appropriate word) was the failure of many of the SAS missiles to leave the launcher after being fired. These remained unfired but active, and had to be extracted, regardless of the recommended safety drills. The battle instantly invoked rifle fire from the surrounding hills. Describing the encounter soon afterwards, the journalist Brian Conne $1{ }^{10}$ wrote:

'Outlying rebel pickets retreated slowly and the SAS picked them off one by one. The rebels still had a mortar firing from the crevice behind the cave, but the SAS had laid on air support. As Venom aircraft came swooping in, one of their rockets made a direct hit. Mortar and men were destroyed immediately.' 
In actual fact, the Venoms had been concealed out of sight and sound, awaiting a simple radio signal to initiate the assault which lasted for precisely 15 minutes; during which time the SAS Troop effected an orderly co-ordinated group withdrawal. The withdrawal developed into a fighting retreat, in which the SAS personnel moved back singly or in pairs, utilizing every scrap of cover available. This endured for rather more than 15 minutes, and was covered by a .3 in Browning machine-gun from the nearest high ground held by the SAS.

The rebels were entrenched in positions and caves known as the Aquabat al Dhafar; and, in order to help the SAS work round this feature, a platoon of the Muscat Regiment was sent up to hold a firm base from which the SAS could work forward. However, it soon became apparent that the rebels had reinforced their positions and could only be dislodged by a conventional assault. This was not the role which was intended for the SAS in isolation. Thus, the Sultan's forces contented themselves with holding the firm base established by the SAS on the summit, in order to encourage Talib to divert troops to that sector from the other positions on the Jebel. At the end of December 1958 a Squadron of the TOS moved to the Awabi front and established a firm base at Hajir. From this point they maintained two Troops on the summit of the Jebel, reinforcing the Muscat Regiment and SAS contingents already based there. Later a dismounted party of 20 Life Guards transported eight Browning machine-guns to the top of the Jebel, and a platoon of the NFR also joined the party. This provided the SAS with sufficient support to launch a strong attack on the Aquabat al Dhafar. The attack was supported by machine-gun fire of the Life Guards' Brownings and the mortars of the Muscat Regiment. It was a night attack in characteristic SAS style. Utilizing ropes to scale the steep cliffs, the attackers surprised their opponents. Close quarter fighting ensued, both sides shouting rude remarks at the other. However, the enemy stubbornly held their ground, despite suffering casualties (the SAS incurred none), and this increased the SAS respect for the rebels.

\section{The SAS is reinforced:}

At this point, Maj Watts, 'D' Squadron's Commander, and Smiley reviewed the SAS activities to date. It was agreed that the prospects of successfully completing the operation with only one Squadron was remote because the terrain was such that the patrols had to be larger than orig- inally intended. It was further agreed, as a consequence, that a second Squadron of the SAS could guarantee successful completion of the task. Accordingly, a signal was sent to DeaneDrummond asking if he was willing to produce a second Squadron; to which he replied in the affirmative, adding that he himself would arrive with a small $H Q$ to take command of both Squadrons. Secondly, agreement had to be obtained from both the Foreign and War Offices. The Political Resident in Oman agreed to forward the request, which was supported by both $\mathrm{HQ}$ British Forces Arabian Peninsula (BFAP), located in Aden, and HQ Land Forces Persian Gulf (LFPG), located in Bahrain.

On 1 January 1959 Deane-Drummond and his $\mathrm{HQ}$ arrived. It was thenceforward decided to establish a joint SAS/SAF/RAF HQ to conduct future operations. Thus, on 9 January, Tac $H Q$, as it was termed, was established at Nizwa; in the same camp as the NFR. In order to streamline the command structure, and in order to avoid any complications regarding whom should command whom in the various units in Oman, Deane-Drummond was appointed Deputy Commander; this meant, in effect, that he had the power to issue orders to any of the units that were deployed at that time; whether British Army, TOS, or SAF. On 12 January 1959 'A' Squadron, 22 SAS Regiment, arrived from Malaya by air, under the command of Maj John Cooper, one of the longest serving officers in the SAS (having served with the unit in its formative service in the Western Desert in World War 2). 'A' Squadron was sent at once to relieve ' $D$ ' Squadron and to acclimatize themselves. At this point in time it was extremely cold on the summit of the Jebel. Troops in the Aquabat al Dhafar area had already reported the water in their bottles freezing, whilst it had hailed on more than one occasion, and once even snowed. Fires at night were thus absolutely essential, even at the risk of snipers' bullets. (In actual fact both sides incurred this risk, and at no time did the fires attract snipers' bullets.)

\section{Planning the assault:}

Timing, and other methods of approach: Whilst this re-organization was under way, planning was initiated for what was hoped would be the final assault upon the Jebel Akhdar. It should be emphasized that, at this juncture, a contracting time scale rendered it urgent that the operation be successfully completed before the end of March 1959. The SAS was due back in the UK by 
the first week in April; whilst climatic conditions necessitated that the other British units also return at this time, as they could not have withstood the appallingly hot weather that commences at the beginning of April. Thus, there were rather less than three months within which to complete the task. The full moon period occurred at the end of each of the three months; and, as it had already been decided that the assault would best succeed at full moon period periods, the last weeks of January, February and March were considered to be the most propitious for the attempt. In all the planning the central objective remained that of seizing the summit of the Jebel Akhdar from which further operations would be mounted.

The Aquabat al Dhafar was too far away from the principal rebel villages of Habib, Saiq, and Sharaijah. Moreover, the enemy were firmly established in this region. This ruled out the area as a principal objective. Nevertheless, the Aquabat al Dhafar was selected for a diversionary move; if the enemy could be encouraged to expect the main assault to be directed at this area, he might divert men there from other areas.

The SAS wished to seize a feature on the summit of the Jebel in the shortest possible time, preferably unopposed, and thus demanding a strong measure of surprise. The three shortes tracks to the rebel villages were the Tanuf, Kamah and Sumeit tracks; all of which were known to have enemy pickets astride them. After a reconnaissance by air, Deane-Drummond decided to select a feature of the ascent between the Wadis Kamah and Sumeit.* This was a climber's route rather than a track, a fine line along a steep ridge $4000 \mathrm{ft}$ in height extending like a fox's brush into low ground held by the Sultan's forces near the village of Kamah. It appeared passable for donkeys except for a portion near the top where a sharp ridge, known as Causeway, connected the first main feature (Pyramid) to be climbed to the actual top of the Jebel (Beercan). It was hoped that the sappers could improve the accessibility of this sector of the route for the donkeys. There were three principal advantages attached to this route. First, it was unguarded. Second, and following from this first characteristic, it was extremely improbable that the enemy would expect the main assault in this direction and would, therefore, be taken by surprise. Thirdly, it could be climbed in one night, so that by dawn the leading troops would be established on top of the jebel where they could be supplied by air.
Smiley had received instructions from BFAP that all troops in the Oman were to be used in support of the SAS. This understandably caused some disappointment to the SAF and TOS personnel who had been engaged for so long in the conflict; and especially, perhaps, to the Muscat Regiment, which had, in actual fact, first penetrated to the summit (cf. above). Nevertheless, the SAF and TOS had an important role to play: first, in making the vital diversionary attacks prior to the main assault; secondly, in taking control of the features as the SAS captured them; and, finally, holding the firm base on the summit of the Jebel Akhdar from which the SAS would operate forward. Upon successfully reaching the top of the jebel, the plan was to adopt an ad hoc response, dependent upon the enemy's reaction, the actions of the rebel leaders, etc. However, if little or no opposition was encountered, it was intended to push patrols on the villages of Habib, Saiq and Sharaijah, whilst the Kamah track would be simultaneously cleared of the enemy and made completely accessible to donkey supply columns.

\section{Deceptions and final plans:}

At this point in time, the enemy had gained a shrewd idea that an assault was imminent. Accordingly, a deception plan was put into effect. 25 January was chose as D-Day, mainly due to the moon. It was essential that at least 24 hours of good weather followed the assault in order for the air drop to be made; otherwise the assault troops would arrive on top of the Jebel short of food, water and ammunition. Before DDay the following diversions were made:

(i) Between 8 and 22 January 'D' Squadron, SAS, and 'A' Company, NFR, effected offensive patrols in the Tanuf area and occupied some high ground normally used by the rebels and an observation post.

(ii) Between 18 and 22 January ' $A$ ' Squadron, SAS, and a Squadron of the TOS effected offensive patrols in the Aquabat al Dhafar region. On the night of 23 January ' $A$ ' Squadron, leaving one Troop and the TOS in the Aquabat al Dhafar area, crossed over the Jebel and down to Tanuf.

(iii) During the night of 23-24 January, 'A' and 'C' Companies of the NFR were to launch the maximum diversionary attacks in the Tanuf and Izki areas respectively.

(iv) On the night of 24-25 January, the leaders of the donkey drovers were told in the stricktest confidence that the assault would be 
directed at the Tanuf track. In actual fact, they were threatened with death if they disclosed the secret. It is believed that the news reached the rebels within a remarkably short space of time (within less than 24 hours in fact).

It was hoped that as a result of all these diversions the rebel leaders would be thoroughly confused as to the main thrust of the assault. Subsequent events were to prove that this hope was completely fulfilled, as it later transpired that, on the morning of the assault, both Talib and Suleiman bin Himyar were situated in the Aquabat al Dhafar area, where they expected the main assault to be launched; a good eight hours march from 'Beercan'.

Having thus planned the diversionary aspects of the operation, it remained for the final assault plan to be finalized. To reiterate in brief, the object was to seize 'Beercan' on the top of the Jebel, and a further feature overlooking Habib, called 'Colin'. The final plan assumed the following form

\section{The assault was to be divided into three phases:}

- The first phase was the capture of 'Pyramid', 'Beercan' and 'Colin' by 'D' Squadron, SAS, and 'Vincent' (a feature approximately one third of the distance to 'Pyramid') by ' $A$ ' Squadron, SAS, by first light on $D+1$

- In the second phase, 'A' Squadron, SAS, was to be relieved by ' $C$ ' Company, NFR, and 'Pyramid' to be taken over by a dismounted Troop of the Life Guards.

- The third phase comprised the consolidation of 'Colin' by ' $D$ ' Squadron, SAS, and ' $A$ ' Squadron's consolidation of 'Beercan'

In addition to the regular troops, there were also two parties of tribal irregulars. On the south side of the Jebel, 50 Beni Ruawha, under the command of Maj Clarke, were to accompany the SAS Squadrons; whilst on the north side 200 Abryeen, strengthened with a platoon of the Muscat Regiment under Maj Coats, were to create a diversion from the Awabi area and, if unopposed, were to climb to the top of the Jebel by means of two tracks from that direction. Further support was to come from the Royal Air Force; No 8 Venom Squadron, based at Sharjah, was to provide close fighter support, whilst three Vendettas from Bahrain were to make nine supply drops on 'Beercan' on the morning of $D+1$.
Two helicopters were also stationed at Nizwa to evacuate any casualties to the Field Hospital already established there.

One final point in planning - and that which was to ultimately cause the major problem - was that of the donkey columns. Some had to accompany the assaulting troops on the first night, whilst others had to be ready to move up the Kamah track once it had been cleared on enemy fire. The importance of the donkeys lay not only in the transport of arms, ammunition and water for the assault troops but also, in the event of bad weather causing the air drops to be aborted, the donkey loads would be vital.

\section{The Assault:}

All diversionary attacks took place as planned. From the later interrogation of prisoners, it became evident that these diversions created the desired effect. Due to unfavourable weather forecasts of clouds being below the top of the Jebel, the final assault was postponed for 24 hours, which proved to be the correct decision. The enlarged Troop from 'D' Squadron, SAS, which participated in the feint attacks in the Tanuf area, in conjunction with the NFR (cf. above), effected a secret withdrawal in the darkness to join the remainder of the Squadron for the main assault. It was a long march off the mountain to the collection point at Wadi Tanuf, whence lorries ferried the men 15 miles to their rendevouz with the rest of the Squadron, and the beginning of the second - and major - climb. Each soldier carried at least $60 \mathrm{lbs}$ weight, most of which was ammunition. Behind the SAS Squadron came a Troop of Life Guards on foot and a company of the NFR, hauling protesting donkeys laden with machine guns.

The untried route was tested by Capt de la Billière's leading Troop. Almost three quarters of the way up, the Troop encountered just one .5 in machine-gun whose two-man crew was in a position, to quote Deane-Drummond, to 'have mown down the attackers in the moonlight, but they had withdrawn to their cave secure in the knowledge of ... centuries that the Jebel was impregnable.' The guardians of the Browning were asleep when the SAS reconnaissance Troop encountered them. They were left to sleep on, with the SAS guard watching over them. Guerrilla piquets on the other side of the plateau, around Sabrina, had now been increased to some 100 , whilst the remainder of their force was 
concentrated at Tanuf. From the startline at the base of the Jebel to the peak of 'Pyramid' consumed nine and a half hours of hard climbing From 'Pyramid' to 'Beercan' the high ridge known as Causeway had to be negotiated, and this proved to be totally impassable for donkeys. At this point a difficult choice confronted Maj Watts, leading ' $D$ ' Squadron, and the CO, Deane-Drummond. They could either move a ponderous but well-armed force up the hill, with the risk of falling into the text-book trap of mountain warfare; viz. that of being 'overlooked' by the enemy at sunrise. Alternatively, the Squadron could cache its heavy rucksacks and make a dash for the summit with only a minimum of ammunition. This latter course, had it misfired, could also have been fatal; costly in British lives if even a small group of guerrillas lurked unseen at the top, and politically to say the least. Watts decided on a quick dash. The rucksacks were left at the Cause-way and the main force left to catch up later. With just their rifles and what ammunition they coulc carry, the SAS men slithered down the steep incline of Causeway to begin climbing again, in what was now a race against the sunrise. 'In the final stages', recalls one of the participants in this desperate climb, 'there was a race to be the first on top since the Persians.' The front'runners included Deane-Drummond, Watts and de la Billière. They arrived on the unguarded plateau on the summit of the Jebel 'absolutely shattered', only to be scourged on by DeaneDrummond to advance and consolidate what was still only a tenacious foothold on the guerrilla stronghold. However, there was no apparent enemy reaction, and 'Beercan' was consolidated.

With the dawn came on air strike by Venoms and nine successful parachute supply drops, each consisting of $3000 \mathrm{lbs}$ of supplies. The air attack and parachute drops apparently convinced the few remaining guerrillas on the south side of the plateau that a full scale airborne invasion of the area was in progress. The guerrilla leaders fled, together with their bodyguards.

Near 'Vincent' occurred the only casualties of the assault, when a stray sniper's bullet hit and exploded a grenade in an SAS soldier's pack. He and the two men following him were badly wounded. Although the helicopters evacuated them within a very short space of time - one helicopter landing under mortar fire - two of the three men died within 24 hours (Tpr W. Carter and Tpr A.G. Bembridge). 'C' Company, NFR, came under mortar and machine-gun fire from the area of Kamah, but this was soon silenced by the 5,5's of the Artillery Troop. The leading soldiers of the SAS also came under fire from a .5 in Browning machine-gun in the mouth of a cave. This ceased when an SAS soldier stalked and killed both enemy gunners with a well aimed grenade. The small Somali donkeys proved to be more of a hindrance than a help, and the majority had to be abandoned at 'Vincent', although a few reached 'Pyramid'; conversely, the local Jebel donkeys proved to be most reliable.

\section{Aftermath of the Assault}

As a result of the successful seizure of the summit, the principal rebel villages of Habib, Saiq and Sharaijah were occupied without opposition. The tribal irregulars with Maj Clarke had shrunk from 50 to 15 during the assault, 35 returning to the base of the Jebel, being unwilling to face the climb from 'Pyramid' to 'Beercan'. The 15 who remained were despatched to contact the local population, who were to be told that if they surrendered their weapons they were to be instantly pardoned and immediately released. Only a few initially accepted this offer but, as word spread that no reprisals were to be taken against them, the numbers increased daily. Several days later the 200 Abryeen irregulars, who had by then shrunk to approximately 70 , together with the platoon from the Muscat Regiment, arrived at Saiq with Maj Coates and their Sheikh, Abdulla bin Henna. On their way up the Jebel they had received the surrender of over 70 Awalad Awaimer tribesmen and disarmed them. An all too familiar situation - rooted in many certuries of endemic tribal warfare - had then followed. The irregulars proceeded to embark upon an orgy of looting throughout the Jebel (and, incidentally, tried to shift the blame onto the regular troops). Donkey loads of loot were seen returning to the Abryeen's main village of Hamra, considerably adding to the Sheikh's supply of rifles (and even adding several Bren guns).

Subsequent cave searches proved to be extremely fruitful. Within only a few days the weapons recovered included four .5 in Browning anti-aircraft gusn, nine 3 in or $81 \mathrm{~mm}$ mortars, 14 Bren guns, approximately 100 rifles ans large stocks of American ammunition, grenades and mines (although some were of Polish or Czech manufacture). Markings on the American equipment indicated that its source was Saudi Arabian army supplies. At Saiq the patrols unearthed a system of caves extending into the heart of the 
mountain in a rabbit warren scheme; it was filled with a variety of 'loot', ranging from arms, ammunition and food to a new Singer sewing machine.

Suleiman had been stupid enough to leave behind all his personal correspondence; and, from the 1000 or so which were translated, much valuable intelligence was extracted concerning rebel organization, arms supplies, and rebel helpers or sypathizers. A number of the Sultan's alleged 'allies' proved to be traitors in actual fact; one tribal guard leader who was supposed to be guarding a sector of the road against mining proved to be the principal minelayer himself. Such treachery was as endemic a feature of tribal warfare as looting. Indeed, it proved to be a vital factor in the ultimate escape of the three rebel leaders; as Smiley strongly suspects that the rebel leaders' escape through the cordon around the base of the Jebel Akhdar was aided and abetted by disloyal tribal guards forming part of the cordon. The rebels eventually made their way to Egypt.

For the following fortnight joint SAS/SAF patrols, as well as one from the Life Guards and another from the TOS, covered all the known Jebel tracks, visited villages and known caves, and made detailed maps of the Jebel for future reference. A company of the NFR established a camp at Saiq, and Lt Col Maxwell was appointed Military Governor of the Jebel Akhdar. Only a little work was required to construct a landing strip at Saiq capable of taking twin-engined Pioneers, which effected considerable economies in the necessity for man and donkey power in the transport of supplies. In March 1959 the SAS contingent and ' $D$ ' Squadron of the Life Guards left Oman, the SAS for the UK and the Life Guards for Aden, although their 'A' Squadron relieved them for a further two months.

\section{Conclusions and Lessons}

Although the first conflict in the Oman, centring throughout upon the seizure of the 'Green Mountain' might appear but a minor operation in the arid wastes of the Persian Gulf, it provides a most interesting and illuminating example of the manner in which obscure and little documented episodes of military history embody important concepts. These concepts may be summarized as follows:

- The comparative unimportance of advanced technology within a rural COIN context, and the need for a continuing awareness of this basic truth in assessing the modern role of infantry.

- The manner in which the constraints and inhibitions of 'indirect strategy' can be overcome through the medium of the extremely limited use of force.

- The vital role which 'third world' strategic interests should play in the military considerations of the Western powers.

- The importance of close and harmonious cooperation with indigenous armed forces.

\section{The limited uses of technology and the role of infantry:}

It will be apparent that, throughout this first campaign in the Oman, the geographical and climatic conditions placed the advantage firmly on the side of the rebels. No technological supremacy could redress this balance. Thus, the course of the campaign was moulded by these conditions; to the extent that the time scale of the final assault upon the Jebel was determined to a very large degree by the appalling climate which would prevail after April. This factor was elucidated and confirmed by no less a personage than the (then) Foreign Secretary, Mr Selwyn Lloyd who, in a statement to the House of Commons on 23 July 1957, was categorical that there was 'no question ... of large scale operations by British troops on the ground'. Indeed, he went on to state that, in view of the high temperatures in the Oman at that time of year, it would be an example of military futility to seek to employ ground forces in the desert areas. The clearest illustration of the inadequacy of technological warfare in COIN operations within a hostile terrain was the futility of air power as the sole means of suppressing the insurrection. The Oman insurgency of 1957/1959 finally and irrefutably repudiated the concept of 'air control'; the utilization of air power as the most effective and economical means of policing the factious tribes of the Arabian Peninsula, which had been a keystone of British defence policy in the area since the early 1920's (since the Cairo Conference of 1921 in point of fact). As Phillip Darby ${ }^{11}$ writes:

'The myth had persisted in air force circles that the RAF's air control method was an economical and successful way of dealing with local tribal quarrels. Thus, when the Oman revolt broke out the RAF asserted that it could do the job unaided and the Government, acting on this advice, authorised rocket and cannon attacks on enemy held forts, and certain other operations 
To reiterate the combination of numerous cavernous retreats and sophisticated anti-aircraft weaponry (it will be recalled that four 5 in Browning anti-aircraft guns were recovered) - the latter of which were not so readily available in the 1920 's and 1930's when air power enjoyed unopposed power in the region - powerfully diluted the impact of air operations against the rebels.

This argument certainly does not imply, however, that air power had no role to play in the operations. Indeed, it proved to be a vital supporting factor in so far as the parachute supply drops which followed the final seizure of the summit of the Jebel Akhdar on 26 January was the decisive determinant in ending rebel resistance to the assault troops. Moreover, at an earlier point in the conflict, the use of radio communication with Venom aircraft had been crucial in effecting the disengagement of an SAS unit on the south side of the Jebel in late December 1958. What is argued, however, is that sole reliance upon superior technology - in the form of air power could never have suppressed the insurrection. The American failure in Vietnam is a clear and tragic vindication of this point.

It is a moot point as to whether, had this first Oman war been transplanted into a modern context, the utilization of helicopter-borne troops would have more rapidly overcome the rebels. It should be borne in mind that the succeeding twenty years have witnessed a very considerable sophistication in the military uses of, and technical development of, helicopters ${ }^{12}$. It remains a moot point nevertheless. The IsraeliArab War of 1973 was noteworthy for the fact, amont others, that helicopters proved extremely vulnerable to manually operated SAM missiles. The sophisticated anti-aircraft gunnery (in terms of the late 1950's) available to the rebels would today undoubtedly have had their counterpart in these SAM missiles. Low flying helicopter operations - necessitated by the landing of assault troops on the plateau of the Jebel - would have enabled the rebels to use their SAM missiles - in addition, of course, to small arms fire - with very considerable effect.

Thus, the main thrust of the COIN assault was vested in the infantry; and, within the context of this principal thrust, the decisive offensive operations - the assault upon the terrorist base of the Jebel Akhdar - devolved upon one of the most specialized elitist units within the British Army - the Special Air Service Regiment. When the possibility of SAS intervention was first mooted, in October 1958 (cf. above), Maj (later Gen) Frank Kitson, a pioneer of counter-terrorist warfare since the Mau Mau emergency in Kenya, occupied a sensitive War Office planning post. Kitson's plan for seizing the plateau of the 'Green Mountain' involved the placing of carefully selected British officers in positions at the foot of the mountain, with a nucleus of bodyguards and a 'substantial sum of money', with which to bribe local informers. This, it was hoped, would effect the capture of guerrillas, some of whom would be 'turned around' to work for the government. 'I visualized', Kitson later wrote, 'forming one or two teams of prisoners augmented by some of our own soldiers in disguise'. These groups, he suggested, could then penetrate the plateau. (Such a concept was, in actual fact, an adaptation of the 'counter gangs' successfully developed by Kitson in Kenya). The Kitson plan was tentatively approved, with an elaboration added by General Hamilton: why not use the SAS? In the event, Kitson's plan was superseded by the SAS's own, more direct, method of attack. A quick military solution required climbing experts and an assault team that could operate in conditions of ultra-secrecy. (Kitson's ideas were later incorporated into the concept underlying the plain clothes Military Reconnaissance Force in Northern Ireland, in which members of the SAS served). In short, the abilities required to successfully undertake the assault was in no way dependent upon technological resources but, rather, upon the highly specialized skills of mountain combat troops. (It was, perhaps, not entirely coincidental that supreme control of internal security in Aden was transferred from the RAF to the Army in 1957.)

However, the role of the SAS in securing the final victory in this first Oman war should not detract from the crucial role played by the SAF, and their British contract officers, as well as the TOS, with both seconded and contract officers. It should constantly be borne in mind that it was a Britishofficered unit of these forces (the Muscat Regiment) which first penetrated to the plateau. In actual fact, the SAS spent less than six months in Oman, whereas the NFR, for example, had endured the heat and constant sniping in the environs of the Jebel for almost two years.

\section{The constraints of 'indirect strategy' overcome:}

The extremely limited numbers of SAS personnel involved in the operation proved to be an extremely effective counterweight to the inhibitions 
imposed by 'indirect strategy'; viz. a policy developed to a high degree by Eastern bloc states whereby political and psychological factors are invoked in order to paralyze decisive military action. 'Indirect strategy' may be said to assume two manifestations; viz. exterior manoeuvre and interior manoeuvre. The central feature of the former is to ensure for the protagonist maximum freedom of manoeuvre within terms of the international political-economic-diplomatic community whilst simultaneously paralyzing the enemy within the same spheres by a multitude of deterrant checks. Writing of this question of the psychological dimension of exterior manoeuvre Andre Beaufre ${ }^{13}$ writes:

'The Soviet Union for instance has succeeded in getting everyone to accept the Iron Curtain as a water tight political barrier in an East-West direction; they have turned into their own preserve the ... platform ... of anti-colonialism, while themselves ruling the only colonial empire still in existence ... Be it noted that these 'conquests' are in most cases based on principles fully accepted by the other side. It may therefore be that these ideological positions occupied by the forces of Marxism may one day be 'conquered' by the West; but this presupposes that the latter in their direct strategy have learned the value of thinking and calculating in Soviet terms instead of merely trying to apply juridicial principles which their enemy can use against them.

The UN embodies the victory of the Soviet Union's imposition of multiple psychological checks to the West's freedom of action, whilst maximizing its own. A number of examples immediately present themselves. In 1956 the virtually unanimous condemnation of the AngloFrench-Israeli Suez intervention was paralleled by virtually total silence within the UN concerning suppression of the Hungarian insurrection, almost coincidental in time. A similar approach emerges when one juxtaposes UN reactions to such issues as Vietnam, Rhodesia, South West Africa, Israeli military responses and the recent annexation of the Golon Heights and Taiwan on the one hand; and the Soviet suppression of the insurrection in Czechoslovakia (1968), the intervention in Poland in 1981, the Soviet invasion of Afghanistan in December 1980 (although UN reaction of this occasion was, admittedly, somewhat more aggressive - if predictably futile), the Egyptian breach of the Bar-lev line in 1973 and the pro-MPLA intervention in Angola (1976) on the other.
It should be borne in mind that, in Oman in 1957, memories of the Suez intervention of a year earlier was very fresh in the minds of the international community.

It will be recalled that, when the original British contingent withdrew from the Oman in 1957, it was mooted that this failure to pursue military objectives was fundamentally motivated by political considerations. Similarly, when Smiley requested British reinforcements in June 1958, political considerations restricted the degree of support to a maximum of two battalions. However, the strategic and tactical orientation of the SAS determined that decisive intervention by this unit would be far below the level which could suggest extensive foreign 'intervention', thereby effectively countering the potential application of exterior manoeuvre.

The second manifestation of indirect strategy may be defined as 'interior manoeuvre'; viz. the actual internal dynamics of insurgency. The Omani War of 1957-1959 illustrates the successful combating of interior manoeuvre by a strategem which was to become, in the ensuing two decades, the preserve of the Eastern bloc; viz. the highly successful intervention of military forces not indigenous to the theatre of conflict, in order to consolidate and maximize the effectiveness of the indigenous fources, in the long range strategic interests of the external power. In a major respect the TOS and SAF were, essentially, proxy or surrogate forces serving vital British interests. The defence of the Oman against insurrectionary forces was essential if the vital strategic oil route encompassing the Hormuz Strait and Musandam Peninsula was not to be controlled by client powers of Egyptian nationalism (and ultimately the Eastern bloc which at this time was heavily involved in Egyptian sponsored nationalist pressures).

This concept was to be later manifested in the active intervention by North Vietnamese conventional forces into South Vietnam in 1971, in support of the Vietcong; the vigorous Soviet intervention in Ethiopia in December 1977/January 1978, in which the USSR mounted a gigantic air and sea lift of Cuban troops from Cuba and Angola into Ethiopia; and, of course, the extensive Cuban and East European involvement in the Angolan civil war of 1976, in support of the client MPLA. Admittedly, there are major contrasts between British intervention in Oman in 1957-1959 and these later manifestations of Eastern bloc and Asiatic Communist strategy. If 
one ignores the most obvious contrast of scale or degree, two major and immediate contrasts present themselves. First, the Eastern bloc/Asiatic Communist intervention was directed towards an expansionist policy (i.e. aggrandisement in the Horn of Africa, the south western coast of Africa, and South East Asia); whereas British intervention in Oman was essentially of a defensive nature. Secondly, the interventionist policy was implemented through intermediaries (i.e. at several degrees remove from the power directing the policy). Hence, Cuban forces implemented Soviet ambitions in Ethiopia and Angola; whereas North Vietnam was the surrogate power extending Chinese Communism into South Vietnam. Nevertheless, the underlying principle remains unaltered. It is a tragic testimony to the success of the Eastern bloc in the sphere of exterior manoeuvre that the stratagem was a highly effective instrument of policy when directed by the Communist bloc whilst the Western strategy (i.e. in Vietnam) was in this regard doomed to total failure and defeat.

\section{The new emphasis upon 'third world' strategic considerations:}

The successful suppression of the Oman insurgency of 1957-1959 exercised an impact upon British strategic thought out of all proportion to the extremely restricted nature of the operation (i.e. in terms of both personnel and area of territory involved). In 1961 the Chiefs of Staff asserted that

'Britain must be increasingly prepared to intervene in Asia and Africa and this would be her major military role over the next decade'. ${ }^{14}$

The policy which they sought to pursue, from that point onwards until the 'Europonization' embodied in the 1974 Defence Review, was strategic mobility or the 'fire brigade' approach to power projection; the first successful experiment in which was the intervention in the Oman in 1958/1959. [Indeed, this conflict betwen 'Europeans' and 'third worlders' - which was so decisively won by the former - was mirrored within the SAS Regiment itself. In the early 1960's when the Regiment was actively involved in the Borneo insurgency (1962-1966), the Regiment was effectively divided between the 'Europeans', who felt that the long term future of the SAS - politically as well as militarily - resided in establishing a deep penetration and reconnaissance function with NATO; and the 'third worlders' who su- spected that this course would smother the SAS beneath the bureaucracy of the British Army of the Rhine. (Although the 'European' approach dominated British strategic thought in the 1970's, the SAS escaped the consequences which it was feared would follow; i.e. its highly individualistic character was not smothered by absorption into the NATO bureaucracy).] Admittedly the 'third world' strategic omphasis foundered and lost all political support before the close of the 1960's. The loss of Aden and South Arabia in 1967 (the result of ideologically motivated political capitulation on the part of the British Labour Party then ruling as opposed to any military defeat), and the subsequent decision to withdraw completely from east of Suez in 1971 so undermined confidence in military solutions that Britain was powerless to actively intervene in areas where insurgency profoundly threatened Western interests; as in Rhodesia, Angola and Mozambique. It may appear incredible to conceive of active - but limited - British intervention in areas such as Rhodesia and Mozambique. However, if one compares the situation with that of Oman, the analogy is not as fantastic as it first appears. Oman possessed a ruling administration totally feudal and reactionary in its attitudes and was, therefore, disliked by 'world opinion' at least to the same extent as Rhodesia and the Lusophone African provinces of Portugal. (The comparison of Oman with these Central African territories would be considered invidious by many informed circles with a detailed knowledge of the latter). The threat to Western oil transportation routes was mirrored in the profound danger posed to the Cape route by the destruction of South Africa; to effect which the successful insurgencies in the Central African arc of 'buffer states' was an important component in overall Eastern bloc policy. ${ }^{15}$

That the policy was abandoned in large measure was due to a multiplicity of factors - many not directly related to military considerations. One had the continued economic decline of the UK in the 1960's and 1970's, with its familiar and recurrent repercussion of drastic reductions in defence expenditure; the prevalent leftist ideology (not confined to the Labour Party) which disdained aggressive military responses in favour of the abdication of vital strategic spheres of influence, regarded as both inevitable and desirable (the surrender of Aden to insurgent forces and the decision to withdraw east of Suez was the final major manifestation of this policy); and the successful application of exterior manoeuvre 
by the Eastern bloc states, particularly with regard to American involvement in Vietnam.

Nevertheless, the essential validity of the concept was not undermined by lack of political will to enforce it. It underlies the idea of the 'rapid deployment force' postulated by the United States in response to events in Iran and was to be successfully demonstrated once again in the same theatre of operations - Oman - in the years 1970-1976.

\section{Close co-operation with indigenous military forces:}

The effectiveness of the British military contingent was heavily dependent upon close and harmonious co-operation with the SAF and TOS. The operations of the SAF (in which the NFR featured especially) and the TOS seriously curtailed the extent of arms shipments to the rebels and stabilized the environs of the Jebel Akhdar to the extent that the rebels had initiated peace overtures to the arrival of the first contingent of the SAS. Moreover, both the Muscat Regiment and the TOS reinforced the SAS in the feature designated the Aquabat al Dhafar. That such reinforcements were essential was clearly demonstrated by the resilient and strenuous opposition encountered by SAS units - to the extent of necessitating an air-supported fighting withdrawal - on the south side of the Jebel in the final week of December 1958. The successful and vital support provided by the SAF and TOS was due in no small measure to the British contract officers in their service. These contract officers were certainly no more courageous than indigenous officers would have been. Nevertheless, they occupied a vitally important role in what would otherwise have been an appalling vacuum; viz. in what might be termed the techno-sphere of modern COIN operations. They had a much needed insight into tactical communications.

The attention to the chain-of-command - particular emphasis being placed upon the minimal disruption of the power structure prevailing within the Sultan's military establishment - is a manifestation of the leading role which such cooperation played in the counsels of the British military establishment. The problem was compounded by the additional complicating factor implicit in contract service with a foreign ruler. The British officers who were directing the activities of both British troops and the indigenous military forces, as servants of the British Crown, were beset with the problem of their relationship with their countrymen, whose sole allegiance was to their foreign employers. In a revealing passage ${ }^{16}$ Smiley clearly illustrates this conflict of loyalties which so often attended seconded service:

'With Waterfield I could never wholly relax not, I think, through any fault on either side, but because of our different positions and often conflicting loyalties. Waterfield was first and solely a Sultan's man and his loyalty was entirely to the Sultan; I was an officer not only of the Sultan but of the Queen, and my first duty was to the Queen. The situation inevitably led to misunderstandings between us.'

This factor certainly presented problems for Smiley, as he himself asserts ${ }^{17}$ :

'My position was a strange one as I was under the direct command of the Sultan to whom I owed my allegiance, though a special clause in my terms of service stated that this was providing it did not conflict with my allegiance to Her Majesty.'

\section{Conclusion}

None of the factors implicit in the lessons which may be extracted from this first Oman war may be regarded as mutually exclusive. Thus, it was precisely the extremely limited numbers of British troops involved which simultaneously overcame the constraints of indirect strategy and rendered close and harmonious co-operation with the indigenous forces absolutely essential, in order to maximize the effectiveness of such limited numbers.

Perhaps the most fundamental lesson to emerge from this conflict was the paramountcy of military professionalism; a concept which may be defined in terms of subordinating or suppressing loyalties irrelevant to the demands imposed by the practice of arms in pursuit of the central and common military objective. Such a concept should occupy the highest priority in any campaign; be it of a conventional or COIN nature. It should constantly be borne in mind that in this conflict one had the most bewildering ethnic configuration, overlaid by complex diplomatic/organizational relationships. First, one had the polyglot nature of the forces supporting the Sultan. Only a minority of the Sultan's forces 
were Arabic; the remainder originating in Baluchistan, speaking their own language and possessing their own distinct ethnic loyalties. The officers were entirely British; yet, even within this homogeneous group, loyalties were markedly differentiated between the 'mercenary element', or contract officers, and those who were members of conventional British units (e.g. the SAS and Life Guards). In addition, one had the vital support of the TOS, which provided the main Arab ethnic base to the forces supporting the Sultan; yet was not formally a part of the SAF. Only the highest degree of professionalism on the part of the officers - be they members of the SAF, contract or seconded officers in the TOS, or British units - could overcome this complexity of potentially conflicting loyalties and ethnic divisions. Within the present military context of South Africa - in which the close co-operation of all population groups in a concerted and unified military effort is being constantly stressed - the lesson is certainly not without significance.

*S. Monick, MA, Ph D., FSA (Scott), FRSA.

\section{Bibliography: sources referred to in the text}

(1) Townsend, J: Oman: the making of a modern state. London: Croom Helm; London, New York: St Martin's Press, 1977.

(2) quoted by Boustead, H: The Wind of Morning, London, 1971.

(3) Lunt, Michael: Imperial Sunset: frontier soldiering in the 20th Century. London: MacDonald, 1981, p 114.

(4) Ibid item (3) above, $p 117$

(5) Smiley, David: Muscat and Oman. Journal of the Royal United Service Institution. Vol CV, February-November 1960, p 32.

(6) For a study of Egyptian involvement in insurrection within South Arabia, see:

Monick, S: The Twilight Conflict: operations in the Radfan, May-June 1964. Militaria 8/4, 1978, pp 19-20.

(7) Monick S: Troubled Epilogue: the career of FIt Lt S.M. Kinkead, DSO, DFC, DSC. Journal of the Military Medal Society of South Africa, No 16, May 1980, pp 30-31.

(8) Smiley, David 7 Kemp, Peter: Arabian Assignment. London: Leo Cooper, 1975.

(9) quoted by Geraghty, Tony: Who Dares Wins: the story of the SAS London: Fontana/Collins, 1981, pp 144-145. (Originally published by Arms and Armour Press, 1980.)

(10) Ibid item (9) above, p 145

(11) Darby, Phillip: British Defence Policy East of Suez 1947-1968. Oxford, New York: Oxford University Press, 1973.

(12) Monick S: Pegasus: Airborne Warfare of Two Decades. Pt 2: Trojan Horse: the advent of the Helicopter. Assegai (Journal of the Rhodesian Army), June-August 1976.

(13) Beaufre, Andre: An Introduction to Strategy. London: Faber, 1967.

(14) Ibid item (11) above.

(15) For a fuller discussion of Eastern bloc 'indirect strategy' and its specific relationship to the insurgencies in Rhodesia and the Lusophone African Provinces, as a vital feature of long range policy with regard to South Africa, see:

Monick, S: The War of the Zambezi salient. Armed Forces, January-August 1981.

(16) Ibid item (3) above, p 121, quoting item (8) above, p 92.

(17) Ibid item (5) above, p 34. 